\title{
Review on the Determinants of the Market Supply of Wheat in Ethiopia
}

\author{
Mulat Mengistu \\ Department of Agribusiness and value Chain Management, Debre Markos University, Debre Markos, Ethiopia \\ Email address: \\ mulatmengistu122@gmail.com

\section{To cite this article:} \\ Mulat Mengistu. Review on the Determinants of the Market Supply of Wheat in Ethiopia. International Journal of Business and Economics \\ Research. Vol. 10, No. 3, 2021, pp. 94-98. doi: 10.11648/j.ijber.20211003.12
}

Received: March 2, 2021; Accepted: April 16, 2021; Published: May 8, 2021

\begin{abstract}
Wheat is one of the most important crops produced in Ethiopia and both as a source of food for consumers and as source income for farmers. Wheat is majorly produced on the central highlands south-eastern and northwest parts of the Ethiopia. Secondary data were used to review this seminar paper to address the following issues such as production and productivity of wheat, factors affecting the market supply of wheat to the market, challenges and opportunities of wheat production and marketing in Ethiopia. Different scholar found different results on the effect of access to credit and number of family size on the market supply of wheat so it is controversial determinant factor. According to the finding of different authors, access of Market information, level of education, land size and accessibility of all-weather road affect the market supply of wheat positively and significantly and distance to the market affect the marketable surplus of wheat negatively. Ethiopia is characterized by weak institutional support and inadequate infrastructure. Producers are still facing different problems. Favorable environment for private investment, Supportive and collaborative international wheat research networks available, huge ground and surface water potential in the country, government is highly committed to support seed producers these are also some of the opportunities for wheat production and marketing.
\end{abstract}

Keywords: Market, Supply, Marketable Surplus, Production, Wheat

\section{Introduction}

\subsection{Background of the Review}

In sub-Saharan Africa, Ethiopia is the second largest wheat producer following south Africa. The area of wheat cultivation had increased from 1.40 million ha in 2004/05 to 1.55 million in 2010/11. In terms of area coverage and annual production, wheat is the third most important cereal crop in Ethiopia following maize and Teff [8]. It is estimated that 1.4 million hectare of land is covered with wheat and more than 2.18 million tons are produced annually [16].

Ethiopia produced 3.9 million tons of wheat in 2013, making it the largest wheat producer in Africa. The second largest producer is South Africa with 1.7 million tons, followed by Kenya with just 0.5 million 9 tons [9]. The Ethiopian Commodity Exchange reported that farm households consume about $60 \%$ of wheat produced; $20 \%$ is sold; and the remainder is used for seed, in-kind payment for labor and animal feed. As indicated above the gap between domestic wheat production and consumption has grown significantly which resulted in higher wheat price. Hence, commercial and subsidized wheat imports have become an option to offset the shortfall in domestic production as well as to stabilize the exorbitant increase in wheat price. For example, in the year 2015/16, EGTE imported 750,000 MT of wheat mainly from Russia and Argentina and around 300,000 MT through food aid mainly from the United States [9].

Wheat becomes a main staple in Africa and sub-due to the result of income growth and rapid urbanization. But subSaharan countries and Africa as a whole produce only about $30 \%$ and $40 \%$ of their domestic requirements respectively; due to a heavy dependence on imports and making the region highly vulnerable to global market and supply shocks [18].

Despite a raise in production and marketable volume, the current level of wheat marketable surplus is still low and insufficient to meet the domestic consumption needs for the growing food processing industries. To stabilize the demand and supply gap, the government of Ethiopia has 
been importing subsidized wheat in the last decade on average of $9 \%$ annually, while production was still increasing on average of $7 \%$ [3].

Difference in wheat marketed surplus among wheat producers was another main challenge in wheat value chain [6]. Thus, Ethiopian government has generically given a great room for industry chains to coordinate supply and demand issues at different functional nodes of value chain to ensure continuous economic growth in the country. Value chain analysis can used to address supply issues such as supply of raw product, quality and consistency of raw product supply in the chains to reduce gap between demand and supply [7].

The domestic consumption of wheat demonstrated the fastest growth trend from 3.72 million tons in 2010 to 5.25 million tons in 2014, which is increased by $41 \%$. Despite the county's attempt to increase wheat production through engaging various strategies, such as enhancing productivity and area expansion, domestic self-sufficiency of wheat both in the form of wheat grain and flour is still far from the plan for the country [24].

\subsection{Objectives}

To review the determinant factors that affects the market supply of wheat product in Ethiopia

To review opportunities and constraints in wheat production and marketing in Ethiopia

\section{Literature Review}

\subsection{Production and Marketing of wheat in Ethiopia}

In Africa, Ethiopia is the second next to Egypt in wheat production which is 4.54 million tons in 2016 [10]. In Ethiopia, Bread wheat (Triticumaestivum), Durum wheat (Triticumturgidum durum) and Emmer wheat (Triticumturgidum dicoccoides) are the major types of wheat which produced in large quantity.

The majorities of the wheat producers are smallholders; and they produced mostly for home consumption and supplying only small marketed surplus [11]. In Ethiopia, large amount of wheat products originates from three main regions of the country which is Oromia 55\%, Amhara 29\% and the Southern Nations, Nationalities, and Peoples Region, SNNPR 9\%. Wheat management practices such as plowing frequency, seed rate, weeding frequency, and crop rotation practices helps to increase productivity and ensure sustainable land management. Timely and required frequency of land preparation is one of the management practices that are recommended by research. To contribute to optimum yield, research advises 3-4 times frequency of land preparation. On the other hand, farmers practice $3-5$ times frequency including planting [22].

In Ethiopia Wheat is produced mainly for consumption and its trend is increasing. In addition to its consumption, it also used for markets; it contributes up to $80 \%$ of the total marketed quantity of cereal production; there is a large demand-supply gap. Smallholder farmers supply only $20 \%$ of production and $80 \%$ of their total production are used for consumption; the per capital share of quantity consumed in pastoral areas, humid low highlands, small and large cities are $20 \%, 1 \%, 6 \%$ and $9 \%$ of all food consumptions respectively [25]. In Ethiopia, wheat is exported to and imported from abroad for gaining the advantage; but the importing and exporting quantity and value are not balanced. Currently importing wheat product and distributing to millers in subsidized form helps to stabilize the wheat price and finally to cease it by producing and selling more [14].

Table 1. Area harvested, production and productivity of wheat in Ethiopia (2008-2016) Area.

\begin{tabular}{llll}
\hline \multirow{2}{*}{ Year } & $\begin{array}{l}\text { Area covered } \\
\text { (ha) }\end{array}$ & Production & Yield \\
\cline { 3 - 4 } & 1696083 & Production (tons) & Yield (kg/ha) \\
\hline 2016 & 1664565 & 4537852 & 26755 \\
2015 & 1663845 & 4650934 & 27941 \\
2014 & 1605654 & 3925174 & 25433 \\
2013 & 1627647 & 3434706 & 24446 \\
2012 & 1437485 & 2916334 & 21102 \\
2011 & 1553240 & 2855682 & 20288 \\
2010 & 1683565 & 3075644 & 18385 \\
2009 & 1424719 & 2314489 & 18269 \\
2008 & 1424719 & 2314489 & 16245 \\
Minimum & 1696083 & 4650934 & 16245 \\
Maximum & 1595200.33 & 3549156 & 27941 \\
Average & 1 & & 22096 \\
\hline
\end{tabular}

Source: CSA, 2017

From the above reviewed data, the production of wheat in the country become increasing, with the changes, from $2,314,489$ in 2008 to $4,537,852$ tons in 2016 . The minimum and maximum wheat output was recorded in the year 2008 and 2015. The area coverage for wheat has increased from 1.4 million hectares in 2004/5 to 1.6 million hectares in 2016. The central highlands of Ethiopia, south-eastern and northwest parts of the country are the major wheat growing areas.. Generally, in Ethiopia wheat is produced by smallholder farmers and the wheat production and productivity and land allocation for wheat production increases from year to year [10].

\subsection{Determinants of the Marketable Surplus of Wheat in Ethiopia}

The following factors were identified and analyzed by using truncated regression model: Education level and Number of oxen are the major variables affecting the intensity of wheat marketing significantly and positively [12]. Similarly, the study conducted in Ghana found that market information and extent of agricultural commercialization, number of years of education influenced the extent of agricultural commercialization positively and significantly [15]. In the same way, a study conducted in Ethiopia the number of oxen owned affects market supply cereal crop positively and significantly [1]. On the other hand, Distance from market is another potential variable which affected the intensity of wheat marketable surplus 
negatively and significantly. Study conducted by Ayalew Y on factors affecting fruit supply to the market find an evidence on distance to market affects the supply of fruit to the market negatively and significantly.

According to Muhammed $U$ the following factors were identified and analyzed by using OLS estimation.

Volume of wheat produced and Access to credit are the variables that influence the volume of wheat supplied to the market positively and significantly [17]. The studies conducted by Wolday A,found that the amount of grain, rice, red pepper, sesame, cotton and honey, produced by household affects marketable supply of each of the commodities significantly and positively [26]. On the other hand, According to Berhanu and Hoekstra, by using probit model, access to credit had negative and significant effect on the supply of wheat product. To conclude this, when households get access to credit they prefer to start other business generating activity rather than producing wheat products [6].

According to Nicholas $\mathrm{M}$ et al the following factors were identified and analyzed by using logistic regression

The age of household head: it affects the household's participation on market supply of wheat negatively and Family size, Land size, Accessibility of all-weather road and nearest to cooperative: it affects the household's participation in wheat market supply positively and significantly [19]:

According to Sultan the following factors were identified and analyzed by using OLS model. Farmers experience in wheat production, total farmland, volume produced of wheat, land size, livestock ownership positively and significantly affected volume of wheat supplied to market [21]. Family size affected volume of wheat supplied to market negatively and significantly [21]. The amount of tomato, papaya, avocado and mango produced by farming households has positive influence on marketable supply of the commodities significantly [5]. It also found that the amount of tomato produced, potato and cabbage affects quantity supplied to market positively and significantly [2].

According to Mohammed $U$ by using multiple linear regression, the following factors were identified such as the quantity of Teff produced, access to market information, access to extension and sex of household head were affected or influence the marketable supply of Teff. Likewise, quantity of wheat produced, and access to credit were found to influence marketable supply of wheat positively and significantly [17].

According to Haymanot A, the following factors affect the marketable surplus of wheat: Lagged market prices, Sex of household heads, Amount of credit and Wheat land size are the variables affecting the volume of wheat marketable surplus positively and significantly [13].

A study conducted by Ayelech $\mathrm{T}$ identified factors affecting the marketable surplus of fruits by using OLS regression. She found that fruit marketable supply was affected by; education level of household head, quantity of fruit produced, fruit production experience, extension contact, lagged price and distance to market [5]. Similarly, the study conducted by Muhammed $U$ on wheat and Teff market chain analysis in Halaba special woreda found credit access has significant and positive effect on the marketable surplus wheat because if the households get credit access they can purchase the required amount of factors of production to increase the production of wheat and to supply more to the market [17]. On the other hand, Family size affected the market supply of wheat negatively and significantly [4].

To the contrary of this a study conducted by Woldemichael $\mathrm{S}$ on the factors that affect milk market supply using Heckman model and his survey results showed that family size had positive impact both on milk sale volume and milk market participation decision. So, the effect of the family size on the marketable surplus of the commodity depends on the consumption habit of the family member to the given products [27]. A study conducted by Berhanu and Hoekstra find evidence of $U$ shaped relationship between age of household head and market participation in the cereal crops, indicating the need for a learning period before households embark on producing for the market [6].

A study conducted by Nicholas; Haymanot and Sultan To the contrary of the above effects of variable on wheat market supply found different results on the effect of family size on market supply of wheat $[19,13,21]$. Family size has positive effect on market supply of wheat because he believe that when the family member become increase the productivity of family labor become increase due to this the market supply of wheat to the market become increase [21].

Family size has negative effects on the marketed supply of wheat, because they believe that, when the family member become increase, at the same time the consumption of wheat become increase due to this the supply of wheat to the market become decline $[21,13]$. Therefore, to conclude this large number of family size has negative effects on the marketable supply of wheat because the resources allocated to wheat production is limited in this case when large number of family labor is added in wheat production activity, the production of wheat does not increase so, the effect of family size on marketable supply is negative.

According to Nicholas $M$ the age of the household head affects the wheat marketable surplus negatively and significantly i.e. when the age of household increase by one year wheat marketable surplus become decreased but the age squared of the household head is positive it indicates that at some earlier period of wheat household age, the relation was negative as it was shown by the negative sign of age variable, but latter on when the wheat household gets older, the wheat supply become increase [19].

To conclude this, the age has negative effect on the supply of wheat because at the early stage of wheat production, the producers may not have enough experience to produce amount of wheat, if the age of household is not older they want to perform other business generating activities and at the early stage of production the producers may not adopt improved technology due to this the market supply of wheat become decline but when the household head age become 
increase they become experienced in wheat production and through time producers can adopt the improved wheat technology to increase production and productivity of wheat at the same time the market supply of wheat become increase.

\subsection{Challenges and Opportunities for Wheat Production and Marketing in Ethiopia}

According to Muhammed $U$ the following major wheat production and marketing problems were identified:

Rain failure, higher fertilizer price and delayed delivery, Lack of credit access, Prevalence of crop diseases were the major problems that reduce wheat production and productivity, unfair pricing system and cheating of traders at the time of weighting, Lack of market information providing institutions, higher input price from Chemical herbicides adulteration are the major marketing problems that lower the gain of the farmers from wheat product. Generally, Based on farmers' perception the major production and marketing problems reported were rain failure, soil erosion, higher fertilizer price and delayed delivery, prevalence of disease, access to credit, poor extension support services, lack of draft power, labor shortage, unfair pricing and scaling (weighing), lack of market information providing institutions [17].

According to Tadele $\mathrm{M}$ et al the following challenges and opportunities were identified in wheat production and marketing: Limited supply of seeds of improved wheat varieties, inadequate knowledge, lack of access to chemicals on time and chemical storage problem, Wheat rust disease, Supply of mixed grades (poor quality) of wheat to the markets by traders, shortage of wheat supply for processing industry, unfair pricing and cheating of traders on balance, unsorted and ungraded supply of wheat, limited production of wheat flour in processing factories due to shortage of wheat supply, existence of Weak market linkages among value chain actors and less bargaining power of farmers are the challenges in the wheat production and marketing of wheat [23].

Contract default due to the poor quality of wheat farmers contractual agreement cannot sustain, lack of market information and lack of working capital limits the participation of different actors in the wheat production as well as the marketing of wheat and price instability i.e. during the peak production season of wheat price become fall and during the off season the price become rise so this conditions does not create favorable conditions for wheat producers [20].

Table 2. Summary of wheat production and marketing problems.

\begin{tabular}{ll}
\hline Production problems & Marketing problems \\
\hline Rain failure & Unfair pricing and cheating \\
High price of fertilizer and delayed delivery & Lack of market information \\
Lack of credit access & Higher input price \\
Crop disease & Weak market linkage among value chain actors \\
Wheat rust disease & Unsorted and ungraded supply of wheat \\
Limited supply of improved wheat seed & \\
\hline
\end{tabular}

According to Tadele $\mathrm{M}$ et al the following opportunities of wheat production and marketing were identified: Government highly committed to support seed producers, favorable environment for private investment, options of improved seeds of wheat available in research centers, availability of various processing plants, high demands for inorganic fertilizer, supportive and collaborative international wheat research networks, huge ground and surface water potential in the country, traders and processors willing to pay premium prices for supplies of quality wheat product [23].

According to Muhammed M the following opportunities for wheat production and marketing were identified: Suitability of the area for production, increased numbers of population, suitable agricultural policy is some of the opportunities for wheat production as well as wheat marketing. Therefore, different stakeholders should involve in the production of wheat to utilize different opportunities and to overcome the challenges [17].

Table 3. Major wheat production and marketing opportunities.

Production and marketing opportunities

Favorable environment for private investment

Availability of various wheat processing plant

Huge ground and surface water potential in the country

Increased number of population

\section{Conclusion and Recommendation}

\subsection{Conclusion}

The findings of review data indicates that, Education level, number of oxen owned, quantity of wheat produced, experience in wheat production, total farmland, size of landholding, livestock ownership, Lagged market prices, Sex of the household heads, amount of credit are the variables affecting marketable surplus of wheat positively and significantly. On the other hand, market distance, access to credit, age are some of the factors that affect the market supply of wheat negatively and significantly.

Different scholar found different results on the effect of access to credit and number of family size on the market supply of wheat so it is controversial determinant factor. There are different constraints in wheat production and marketing in Ethiopia, which includes limited supply of seeds of improved wheat varieties, inadequate knowledge, lack of access to chemicals on time and chemical storage problem. In Ethiopia, not only the constraints but also there are different opportunities for wheat production and marketing in Ethiopia. These opportunities includes, favorable environment for private investment, supportive and 
collaborative international wheat research networks available, huge ground and surface water potential in the country, government highly committed to support seed producers.

\subsection{Recommendations}

Most of the wheat production is held by smallholders so producers should follow cluster production system to increase the production and productivity of wheat because it enables the producer to use different technology like tractor, harvester etc.

The results of the review data revealed that the existence of different challenges and opportunities in the wheat production and marketing so the producers, government and other stakeholders should form cooperation in order to minimize the challenges and expand and use the opportunities for wheat production and marketing in Ethiopia.

Different scholar found controversial result on the effect of access to credit and family size on the market supply of wheat. Therefore, further studies should be conducted.

\section{References}

[1] Abafita J, Atkinson J, Kim CS (2016). Smallholder Commercialization in Ethiopia: Market Orientation and Participation. International Food Research Journal, Vol 23.

[2] Abraham T (2013). Value Chain Analysis of Vegetables: the case of Habro and Kombolcha Woredas in Oromia region, Haramaya University, Ethiopia. MSc Thesis.

[3] ATA (2014). Agricultural Transformation Agency.

[4] Ayalew Y (2015). Factors affecting fruit supply in the market: The case ofhabru woerda, North Wollo, Ethiopia. European Journal of Business andManagement 7: 309-318.

[5] Ayelech T (2011). Market chain analysis of fruits for Gomma woreda, Jimma zone, Ethiopia.

[6] Berhanu, G and Hoekstra D (2007). Cereal marketing and household market participation in Ethiopia: The case of teff, wheat and rice. AAAE conference proceedings (Pp. 243-252).

[7] Bryceson KP. (2008). Value chain analysis of bush tomato and wattle seed products, DKCRC Research Report 40. Desert Knowledge Cooperative Research Centre, Alice Springs.

[8] CSA (Central Statistical Agency) (2012). Agriculture Sample Survey Volume IV Report on Area and production of crops (Private Peasant Holdings, Meher Season) Addis Ababa, Ethiopia.

[9] CSA (Central Statistical Agency) (2014). Agricultural sample survey report on area and production of major crops. Statistical Bulletin (532), Volume VI, Addis Ababa, Ethiopia.

[10] CSA (Central Statistical Agency) (2017). Report on Area and Production of Major crops. Ethiopian Agricultural Sample Survey Private Peasant Holdings, Meher Season Volume I. Statistical Bulletin. Addis Ababa
[11] EDRI (Ethiopian Development Research Institute) (2012). Consumption, saving and Investment Behaviors of successful farmers in Ethiopia.

[12] Gezachew F (2018). Factors Affecting Marketing Intensity of Wheat Growers in Southeastern Ethiopia.

[13] Haymanot A (2014). Durum wheat value chain analysis: the case of Gololcha district of bale zone, ethiopia., Ethiopia.

[14] Mamo T, Getahun W, Tesfaye A, Chebil A, Solomon T, AwHassan A, Debele T and Assefa S. (2017). Analysis of wheat commercialization in Ethiopia: The case of SARD-SC wheat project innovation platform sites. African Journal of Agricultural Research, 12 (10), pp. 841-849.

[15] Martey E (1980). Market Information and Extent of Agricultural in Effuto municipallity of Ghana, American journal of Experimental Agriculture 4; 1680.

[16] MoARD (Ministry of Agriculture and Rural Development). (2005). Majo Agro-ecological Zones of Ethiopia. Forestry, Land Use and Soil Conservation Department. Addis Ababa, Ethiopia.

[17] Muhammed U (2011). market chain analysis of teff and wheat production in halaba special woreda, southern ethiopia. msc thesis haramaya university.

[18] Negassa A, Jawoo K. Sonder, B, Shiferaw M, Smale H. J., Braun, D, Hodson S, Gbegbelegbe Z, Guo S, Wood, Payne T, and Abeyo B (2012). The Potential forWheat Production in Sub-Saharan Africa: Analysis of biophysical suitability and economic profit.

[19] Nicholas M, James W, Leulsegged K, Abate G and Shahidur R (2015). The Wheat Supply Chain in Ethiopia: Patterns, Trends, and Policy Options.

[20] Samuel Gebreselassie; Mekbib G, Matthias K (2017). The Wheat Sector in Ethiopia: Current Status and Key challenges for future value chain development.

[21] Sultan (2016). Analysis of wheat value chain: the case of sinana district, bale zone, oromia region, ethiopia msc thesis, haramaya university.

[22] Tadele Mamo, Tewodros Tefera and Noreen Byre (2014). Factors influencing urban and periurban dairy producers' participation in milk value addition and volume of milk value.

[23] Tadele M, Wudineh G, Agajie T, Tesfaye S, Ali C and Tolessa D (2018). wheat value chain analysis the case of innovation platform sites SARD. SCwheat project.

[24] USDA (2013). Ethiopia Grain and Feed Annual Report, Global Agricultural Network Information, GAIN report number ET-1301.

[25] USDA (United States Department of Agriculture) (2014). Ethiopia. Grain and Feed Annual, Agrocharts News, Apr 2014.

[26] Wolday A (1994). Food Grain Marketing Development in Ethiopia after Reform 1990: A Case of Alaba study of halaba Siraro (p. 293, The PhD Dissertation Presented to Verlag Koster University, Berlin). Study of Alaba.

[27] Woldemichael Somano (2008). Dairy marketing chains analysis: the case of shashemane Ethiopia. 